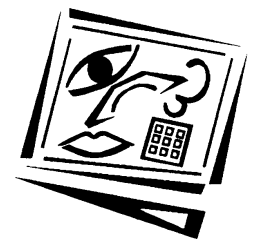

\title{
Analysis of the technology acceptance model in examining students' behavioural intention to use an e- portfolio system
}

\author{
Ronnie H. Shroff, Christopher C. Deneen and Eugenia M. W. Ng \\ The Hong Kong Institute of Education
}

\begin{abstract}
In recent years, instructors have had an increasing interest in integrating Internet based technologies into their classroom as part of the learning environment. Compared to studies on other information systems, student users' behaviour towards e-portfolios have not been assessed and thoroughly understood. This paper analyses the Technology Acceptance Model (TAM) in order to examine students' behavioural intention to use an electronic portfolio system, meaning how students use and appropriate it within the specific framework of a course. An E-Portfolio Usage Questionnaire was developed using existing scales from prior TAM instruments and modified where appropriate. Seventy-two participants completed the survey questionnaire measuring their responses to perceived usefulness (PU), perceived ease of use (PEOU), attitudes towards usage (ATU) and behavioural intention to use (BIU) the e-portfolio system. The results of the study indicated that students' perceived ease of use (PEOU) had a significant influence on attitude towards usage (ATU). Subsequently, perceived ease of use (PEOU) had the strongest significant influence on perceived usefulness (PU). The research further demonstrated that individual characteristics and technological factors may have a significant influence on instructors to adopt e-portfolios into their courses. Results suggest that TAM is a solid theoretical model where its validity can extend to an e-portfolio context.
\end{abstract}

\section{Introduction}

The utilisation of electronic portfolio (e-portfolio) systems has the potential to change the nature of learning environments and the ways in which student learning is promoted through different modes of learning (Ayala, 2006). E-portfolios allow information to be stored, accessed, updated, and presented in various electronic formats as a record or evidence of student learning and achievement (Chau \& Cheng, 2010; Gaide, 2006). Criteria for a successful e-portfolio system include ease of use, a robust integrated technology architecture, lifelong support, standards and transportability (Jafari, 2002). Subsequently, different e-portfolio systems offer varying levels of robustness and ease of control in terms of managing the flow and appearance of content (e.g., text, multimedia and web links). However, implementing an institutewide e-portfolio system is not only costly, but may also entail the problem of students low adoption rate of the technology (Joyes, Gray \& Hartnell-Young, 2010; Lambert \& Corrin, 2007; Zhang, Olfman \& Reetham, 2007). User friendliness and user acceptance of e-portfolio systems are two of the most problematic requirements to satisfy as "users are known to quickly become frustrated and simply abandon a confusing application" (Jafari, 2004). To increase student acceptance levels, systems administrators and educators should be able to identify a wide range of student preferences, intentions, 
and purposes for using an e-portfolio and should then be able to integrate these factors into the development process, preferably at an early stage (Abrami \& Barret, 2005).

Several models have been developed to investigate and understand the factors affecting the acceptance of computer technology. The theoretical models employed to study user acceptance, adoption, and usage behaviour include the theory of reasoned action (TRA) (Ajzen \& Fishbein, 1980; Fishbein \& Ajzen, 1975), the theory of planned behaviour (TPB) (Ajzen, 1991; Mathieson, 1991), the technology acceptance model (TAM) (Davis, 1989; Davis, Bagozzi \& Warshaw, 1989), the decomposed theory of planned behaviour (Taylor \& Todd, 1995), and innovation diffusion theory (Agarwal \& Prasad, 1997, 1999; Brancheau \& Wetherbe, 1990). However, current research has focused on the technology acceptance model (TAM) because the research seeks to understand the relationship between perceptions (such as perceived usefulness and perceived ease of use of technologies) and usage behaviour.

Considerable discussions emanating from academic debate and research surround the emergence of technology acceptance (Davis, 1993; Gao, 2005; Gong, Xu \& Yu, 2004). Research indicates that, although institutions have made large investments in educational technology, many technologies have been underutilised or abandoned completely, due to limited user acceptance (Liu, Liao \& Pratt, 2009; Park, 2009; Teo, 2009). The technology acceptance model (TAM), developed by Davis (1989), states that the success of a system can be determined by user acceptance of the system, measured by three factors: perceived usefulness (PU), perceived ease of use (PEOU), and attitudes towards usage (ATU) of the system (Davis, 1989). If a system is not easy to use then it will probably not be perceived as useful. According to the model, a user's perceptions about the system's usefulness and ease of use result in a behavioural intention to use (or not to use) the system (Davis, et al., 1989; Nov \& Ye, 2008). Thus, the objective of this study is to examine the relationship of students' behavioural intention to use (BIU) the e-portfolio system with selected factors of perceived usefulness (PU), perceived ease of use (PEOU), and attitude towards usage (ATU), and develop a general model of e-portfolio acceptance.

The following research question seeks to examine students' usage of a system utilising the technology acceptance model (TAM): what are individual student's perceptions of usefulness (PU), ease of use (PEOU) and attitude towards usage (ATU) of an eportfolio system that inform their behavioural intention to use (BIU) the system? Specifically, we try to better understand how these factors support technology acceptance in the context of an e-portfolio system. A thorough understanding of the TAM model may help us to analyse the reasons for resistance toward the technology and would further enable us to take efficient measures to improve user acceptance/usage of the technology. According to Davis (1989), practitioners evaluate systems for two purposes: 1) to predict acceptability; and 2) to diagnose the reasons resulting in lack of acceptance and to take proper measures to improve user acceptance. Overall, the technology acceptance model (TAM) has received empirical support for being robust in predicting technology adoption in various contexts and with a variety of technologies (Gao, 2005; McKinnon \& Igonor, 2008; Park, 2009; Sugar, Crawley \& Fine, 2004; Teo, 2009). The relevance for this study is that an examination of students' usage of an e-portfolio system could contribute to their acceptance of an emerging educational technology that has been developed specifically to respond to current demands of teacher education. 


\section{Background and theoretical framework}

The initial steps in adoption of any information technology consist of establishing what purpose the system will address and what functionality the institution requires. For an e-portfolio system, these are particularly challenging tasks in establishing a 'one size fits all' definition or a corresponding set of standard functionalities (Zhang, et al., 2007). As Internet usage continues to increase, many educational institutions are either purchasing commercial e-portfolio systems or building their own from scratch. Institutes of higher education are beginning to deploy e-portfolio systems to take advantage of the expected gains of supporting a variety of student achievements, both as showcases of student work, for peer and self-reflection, as well as providing a means for a more authentic form of learning assessment (Kong, Shroff \& Hung, 2009; Orland-Barak, 2005; Pelliccione \& Raison, 2009).

Although e-portfolio systems may offer robustness and ease of control, the underlying design model may be limited and rigid in terms of how to manage the flow and appearance of content (e.g., text, multimedia and web links). E-portfolio systems commonly use web-based forms and presentation features comprising of built in forms and predetermined workflows to facilitate student creation of online portfolios for their academic work. The functionalities of e-portfolio systems constitute a challenge for institutions planning to deploy or renew their e-portfolio systems. One challenge is determining whether an established e-portfolio infrastructure can offer a favorable environment for students to make productive reflections for enhancing the quality of learning (Chau \& Cheng, 2010). Abrami and Barrett (2005) noted that tools such as reflective journals, self report surveys and digital storytelling can engage learners in reflection, support learning and facilitate the creation of portfolios. Moreover, the criterion of technology acceptance is fundamental to making sure that the e-portfolio system is used effectively by students.

Application of the TAM model would seem to be favourably indicated for understanding conceptual issues related to e-portfolio use. Use of the TAM is predicated on individuals having control over whether or not they use the system (Pearlson \& Saunders, 2006). The factors in the model, namely perceived usefulness (PU), perceived ease of use (PEOU), and attitudes towards usage (ATU), represent attributes or characteristics of the system, such as the overall design and features of the system, the user's skills and capabilities, and the user's beliefs and attitude towards the system (Davis, 1989; Gao, 2005; Ma \& Liu, 2005; McKinnon \& Igonor, 2008). The behavioural intention to use (BIU) is an important factor that determines whether users will actually utilise the system. For example, Yi and Hwang (2003) found a direct and significant influence $(\beta=0.19 ; p<0.001)$ between behavioural intention and actual usage of the web-based environment in their study. Use of the TAM model for understanding students' perceptions of the e-portfolio system and potential future use is therefore based on the following assumptions:

1. When students perceive the e-portfolio system as one that is useful and easy to use, then they may have a positive attitude towards using the system.

2. When students perceive the e-portfolio system as one that is easy to use, then they may have a positive attitude towards the usefulness of the system.

3. When students have a positive attitude towards the system, they may use the system frequently and intensively and may have a favorable intention towards using the system. 
Several models have been developed in the past three decades to investigate variables that influence individuals' technology acceptance (Agarwal \& Prasad, 1988; Morris \& Dillon, 1997; Thompson, Compeau \& Higgins, 2006). The technology acceptance model (TAM) proposed by Davis (1989) is the classical information systems model developed to explain computer-usage behaviour and factors associated with acceptance of technology. According to this theory, information system usage behaviour is predominately explained by behavioural intention that is formed as a result of conscious decision-making processes. Behavioural intention, in turn, is determined by two belief factors, namely, perceived usefulness (PU) and perceived ease of use (PEOU). By manipulating these two factors, system developers can have better control over users' beliefs about the system, and subsequently, their behavioural intention and usage of the system.

Dillon and Morris (1998) defined technology acceptance as "the demonstrable willingness within a user group to employ information technology (IT) for the tasks it was designed to support" (p. 5). The dominant themes in research focus mainly on instrumental influences, which investigate acceptance decisions involving beliefs as to how using technology will result in objective improvements in performance (Thompson, et al., 2006). Thompson et al. argued that this approach may have had a limiting effect on technology research and broadened their research to include concepts related to non-instrumental influences on technology acceptance. The TAM suggests that perceived usefulness (PU) and perceived ease of use (PEOU) determine an individual's behavioural intention to use (BIU) a system. Hu et al. (1999) suggested that many factors influence initial acceptance of technology, but fundamental determinants (e.g. perceived ease of use and perceived usefulness) play a greater role in continued acceptance.

TAM presumes that behavioural intention is formed as a result of conscious decisionmaking processes (Venkatesh, et al., 2003). The model specifies three belief factors that are salient in the context of information technology usage and acceptance: perceived usefulness (PU), perceived ease of use (PEOU), and attitude towards usage (ATU) (Ajzen \& Fishbein, 2000; Davis, 1989). Perceived usefulness (PU) is defined as "the degree to which a person believes that using a particular system would enhance his or her performance" (Davis, 1989). Perceived ease of use (PEOU) refers to "the degree to which a person believes that using a particular system would be free of effort" (Davis, 1989). Perceived usefulness and perceived ease of use can be considered as cognitive factors. Attitude towards usage (ATU) refers to the "the degree to which an individual evaluates and associates the target system with his or her job" (Davis, 1993). Attitude towards usage has been identified as a factor that guides future behaviour or the cause of intention that ultimately leads to a particular behaviour. In TAM, attitude towards usage is referred to as the evaluative effect of positive or negative feeling of individuals in performing a particular behaviour (Ajzen \& Fishbein, 2000).

\section{Research model and hypotheses}

The technology acceptance model (TAM) is used in this study for its predictive ability in studies involving students (Kiraz \& Ozdemir, 2006; Teo, 2009). The causal relationships between perceived usefulness (PU), perceived ease of use (PEOU), attitude towards usage (ATU), and behavioural intention to use (BIU) technology are specified in the TAM to reflect the new environment of an e-portfolio system. PU is defined as the degree to which an individual believes that using an e-portfolio system 
would enhance his or her performance in the course, whereas PEOU refers to the degree to which an individual believes that using the system would be free of cognitive effort. TAM suggests that actual usage of the system is determined by the users' behavioural intention to use (BIU) the system, which is determined by users' attitude towards using the system and their perceived usefulness and ease of use of the system (Davis, et al., 1989). Together, PU and PEOU constitute a significant influence on ATU, which in turn affect the BIU. In addition, PEOU has also been shown to significantly influence PU (Teo, 2009). Similarly, behavioural intention to use (BIU) the system is posited to be affected by attitude towards usage (ATU). In accordance with the research objective and consistent with the related literature, this study tested the following hypotheses:

$\mathrm{H}_{1}$ : Perceived usefulness (PU) will have a significant influence on attitude towards usage (ATU).

$\mathrm{H}_{2}$ : Perceived ease of use (PEOU) will have a significant influence on attitude towards usage (ATU).

$\mathrm{H}_{3}$ : Perceived ease of use (PEOU) will have a significant influence on perceived usefulness (PU).

$\mathrm{H}_{4}$ : Attitude towards usage (ATU) will have a significant influence on users' behavioural intention to use (BIU) the e-portfolio system.

These hypotheses give rise to the research model (Figure 1) represented as a causal relationship schema and used as a point of departure for this research. The boxes represent the constructs which were measured by a set of items, with arrows representing hypotheses 1 to 4 .

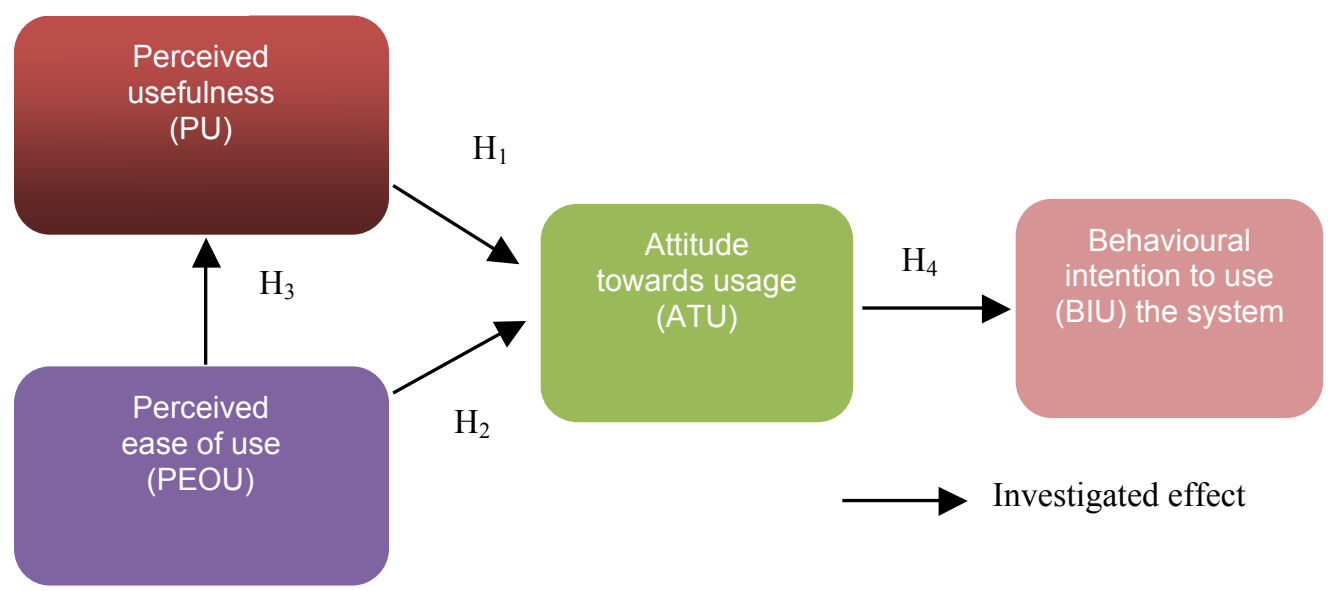

Figure 1: Conceptual research model (Davis, et al., 1989)

\section{Research methodology}

\section{The research setting}

A total of $169(\mathrm{~N}=169)$ undergraduate students enrolled in Bachelor of Education (BEd) Programmes at the Hong Kong Institute of Education (HKIEd) constituted a sufficient pool of available subjects, who fit well within the context and purpose of this study. 
The selection of four courses was based on the following. Firstly, course structure and contents provided sufficient opportunity for students to interact with the e-portfolio system. Secondly, learning activities and assessment in the form of self-reflections were structured into the design and organisation of the courses. The courses ran from the Spring semester January 2010 to May 2010 over a period of approximately 12 weeks. The course instructors made use of the Blackboard 9 e-portfolio system.

\section{Technology}

The Blackboard 9 e-portfolio system was chosen to supplement this study for two reasons. Firstly, the Blackboard 9 learning management system is an existing available resource acquired by the Hong Kong Institute of Hong Kong (HKIEd). Secondly, the Blackboard 9 e-portfolio system not only allowed students to collect and organise artifacts of various forms of media (such as text, images, video, audio) in a digital environment, but also allowed students to organise the artifacts in a number of ways to demonstrate learning over time, to share competencies and to demonstrate mastery of course content. Therefore the reasons for choosing the e-portfolio system also extend beyond the availability and convenience of the Blackboard 9 learning management system in that it provides various pre-built e-portfolio solutions and a structure of customisable tools.

\section{Course design}

The content of the e-portfolio for each of the four pilot courses focused on student reflections upon the artifacts uploaded to the Blackboard 9 learning management system. Students were required to upload their work which included posting video clips and assignments and capturing parts of their reflections or other evidences to justify their claims of 'improvement'. An important aspect of student's participation in their portfolio development included evidence to demonstrate the learning outcomes, whereby students were required to track their development and progress through written reflection which was seen as a critical component of the entire portfolio process.

\section{Measurement scales}

The completed instrument consisted of two sections (See Appendix). Section I was designed to identify demographic attributes of the respondents. It contained demographic items such as academic year, gender, self-assessment, interaction and experience of students' e-portfolio usage. The questions in Section II were based on prior studies with modifications to fit the specific context of the e-portfolio usage and subsequently developed from the TAM scales, adapted from Davis, at al. (1989) and Venkatesh, et al. (2003). All the constructs in the research model were operationalised using standard scales from past literature. Our research TAM model consisted of 20 items (see Table 1) that measured "perceived usefulness" (5 items), "perceived ease-ofuse" (5 items), "attitude towards usage" (5 items) and "behavioural intention to use eportfolio" (5 items). The response scale for all items was a seven-point, positivelypacked Likert scale (Lam \& Klockars, 1982) coded as, 7: Strongly agree; 6: Moderately agree; 5: Slightly agree; 4: Neutral; 3: Slightly disagree; 2: Moderately disagree; 1 : Strongly disagree. 


\section{Data collection}

Both web-based and hard copy versions of the e-portfolio usage questionnaire were administered to 169 students to fill out, with the aid of instructors in charge of each course, wherein the order of items was randomised. The collection of these questionnaires yielded 72 usable data responses. For this study, a power test was conducted to find the appropriate sample size required to provide a test of the appropriate power. The results demonstrated that a sample size of 72 is adequate to detect, with power equal to .80 . With a sample size of 72 , the study had a power of 0.783 to yield a statistically significant result, close within the .80 , a commonly accepted threshold in these analyses (Cohen, 1977). The data collected from 72 responses was analysed to provide evidence for the validity and reliability of the eportfolio usage questionnaire.

\section{Results and analyses}

The process of analysis followed the intent of the study. First, validity of model use in the context of the e-portfolio inquiry was analysed. Having established validity and robust construct relationships, researchers' data results were then analysed. This is followed by testing of the hypotheses by assessing the model fit using various fit indices and evaluating the research model.

\section{Descriptive statistics}

The descriptive statistics of the four factors are shown in Table 1. All means are above the midpoint of 3.00. The standard deviations range from 1.22 to 1.50 indicating a narrow spread around the mean.

Table 1: Summary of means and standard deviations $(\mathrm{N}=72)$

\begin{tabular}{|c|c|c|c|}
\hline Factors & Question & Mean & Std dev \\
\hline \multirow{5}{*}{$\begin{array}{l}\text { Perceived usefulness } \\
\text { (PU) }\end{array}$} & Q9. & 3.32 & 1.509 \\
\hline & Q14. & 4.19 & 1.469 \\
\hline & Q18. & 5.26 & 1.496 \\
\hline & Q20. & 3.00 & 1.473 \\
\hline & Q25. & 5.58 & 1.416 \\
\hline \multirow{5}{*}{$\begin{array}{l}\text { Perceived ease of } \\
\text { use (PEOU) }\end{array}$} & Q12. & 3.42 & 1.422 \\
\hline & Q16. & 4.60 & 1.479 \\
\hline & Q19. & 3.53 & 1.256 \\
\hline & Q21. & 5.54 & 1.401 \\
\hline & Q27. & 3.44 & 1.381 \\
\hline \multirow{5}{*}{$\begin{array}{l}\text { Attitude towards } \\
\text { usage (ATU) }\end{array}$} & Q8. & 3.18 & 1.223 \\
\hline & Q13. & 5.68 & 1.456 \\
\hline & Q17. & 5.19 & 1.507 \\
\hline & Q22. & 4.83 & 1.444 \\
\hline & Q26. & 3.43 & 1.384 \\
\hline \multirow{5}{*}{$\begin{array}{l}\text { Behavioural } \\
\text { intention to use } \\
\text { (BIU) the e-portfolio } \\
\text { system }\end{array}$} & Q10. & 3.10 & 1.474 \\
\hline & Q11. & 3.91 & 1.294 \\
\hline & Q15. & 3.76 & 1.224 \\
\hline & Q23. & 3.91 & 1.302 \\
\hline & Q24. & 3.18 & 1.407 \\
\hline
\end{tabular}




\section{Construct validity}

To test the construct validity of items in the instrument, confirmatory factor analysis was performed and reliability of factors assessed using Cronbach's (1951) alpha. Construct validity was assessed using confirmatory factor analysis (CFA) to test the fit of the data to the model. Table 2 presents the factor loadings of the e-portfolio usage questionnaire for the sample of 72 students using the individual student as the unit of analysis. The results of confirmatory factor analysis indicated that the scales were not only reliable, but also valid for the factors under study.

Table 2: Results of confirmatory factor analysis

\begin{tabular}{|c|c|c|c|c|}
\hline \multirow{2}{*}{$\begin{array}{c}\text { Item } \\
\text { no. }\end{array}$} & $\begin{array}{c}\text { Perceived } \\
\text { usefulness (PU) }\end{array}$ & $\begin{array}{c}\text { Perceived ease } \\
\text { of use (PEOU) }\end{array}$ & $\begin{array}{c}\text { Attitude towards } \\
\text { usage (ATU) }\end{array}$ & $\begin{array}{c}\text { Behavioural intention } \\
\text { to use (BIU) the e- } \\
\text { portfolio system }\end{array}$ \\
\hline 9 & 0.89 & & & \\
\hline 14 & 0.87 & & & \\
\hline 18 & 0.86 & & & \\
\hline 20 & 0.91 & & & \\
\hline 25 & 0.90 & & & \\
\hline 12 & & 0.89 & & \\
\hline 16 & & 0.87 & & \\
\hline 19 & & 0.86 & & \\
\hline 21 & & 0.91 & & \\
\hline 27 & & 0.90 & & \\
\hline 8 & & & & 0.88 \\
\hline 13 & & & 0.92 & 0.87 \\
\hline 17 & & & & 0.89 \\
\hline 22 & & & & 0.93 \\
\hline 26 & & & & \\
\hline 10 & & & & \\
\hline 11 & & & & \\
\hline 15 & & & & \\
\hline 23 & & & & \\
\hline 24 & & & & \\
\hline
\end{tabular}

The factors were analysed using Cronbach's alpha (Cronbach, 1951, 1970). All of the measures employed in this study demonstrated excellent internal consistency, ranging from 0.904 to 0.914 (see Table 3 ), thereby exceeding the reliability estimates $(\alpha=0.70)$ recommended by Nunnally (1967).

Table 3: Cronbach alpha reliability coefficient

\begin{tabular}{|l|c|c|}
\hline \multicolumn{1}{|c|}{ Factor } & Items & Alpha \\
\hline Perceived usefulness (PU) & 5 & 0.953 \\
\hline Perceived ease of use (PEOU) & 5 & 0.958 \\
\hline Attitude towards usage (ATU) & 5 & 0.948 \\
\hline Behavioural intention to use (BIU) the e-portfolio system & 5 & 0.952 \\
\hline
\end{tabular}

\section{Discriminant validity}

Discriminant validity was assessed by inspecting the correlations between the four factors (Bagozzi \& Phillips, 1991). Table 4 shows the average variance extracted (AVE) for each factor and indicates that the questions for each factor correlated with each 
other but were below threshold for intercorrelating with other factors. Thus, the results indicate that discriminant and convergent validity of the measures are reasonable.

Table 4: Assessment of discriminant validity

\begin{tabular}{|l|c|c|c|c|}
\hline \multicolumn{1}{|c|}{ Factor } & PEOU & PU & ATU & BIU \\
\hline Perceived ease of use (PEOU) & $\mathbf{. 5 5 2}$ & \multicolumn{4}{|l|}{} \\
\hline Perceived usefulness (PU) & .287 & .517 & & \\
\hline Attitude towards usage (ATU) & .318 & .297 &. $\mathbf{5 6 1}$ & \\
\hline $\begin{array}{l}\text { Behavioural intention to use (BIU) the } \\
\text { e-portfolio system }\end{array}$ & .262 & .289 & .379 & .427 \\
\hline
\end{tabular}

Diagonal entries: Average variance extracted; Non-diagonal entries: shared variance

Table 5 shows a summary of the overall model fit measures. This model was found to be valid, as evidenced by the adequacy indices such as chi-square statistic, $\chi^{2}(\mathrm{~N}=72)$ $=258, p<0.01$. The chi-square statistic is an intuitive index for measurement goodness of fit between data and model. As recommended by Hair, Anderson, Tatham \& Black (2003), several other fit indices are examined. According to Gefen, Straub \& Boudreau (2000) and Hair et al. (2003), goodness of fit index (GFI), comparative fit index (CFI) and normed fit index (NFI) are best if above 0.90 and demonstrate marginal acceptance if above 0.80 , adjusted goodness of fit index (AGFI) above 0.80 and root mean square residual (RMR) below 0.05. These fit indices indicate that the proposed measurement model exhibited a good fit with the data collected. This study was close enough to suggest that the model fit was reasonably adequate to assess the results for the structural model. Thus, we could proceed to examine the path coefficients of the structural model.

Table 5: Goodness of fit measures

\begin{tabular}{|c|c|}
\hline Fit measures & Values \\
\hline Chi squared & 258 \\
\hline RMR & 0.45 \\
\hline RMSEA & 0.68 \\
\hline GFI & .889 \\
\hline CFI & 0.91 \\
\hline AGFI & .965 \\
\hline NFI & .963 \\
\hline Comparative fit index (CFI), cut-off $>.90$
\end{tabular}

\section{Hypotheses testing}

This study employed a structural equation modeling approach to develop a model that represents the relationships among the four factors in this study: perceived usefulness (PU), perceived ease of use (PEOU), attitudes towards usage (ATU) and behavioural intention (BIU) to use the e-portfolio system. Table 6 shows the results of the hypotheses tests by confirming the presence of a statistically significant relationship in the predicted direction of the proposed research model. Overall, 2 out of 4 hypotheses were supported by the data. Consistent with prior research (Davis, 1989; Hu, Chau, Sheng \& Tam, 1999), perceived ease of use (PEOU) had a significant effect on attitude toward using (ATU), with $p<0.001$. While perceived ease of use (PEOU) had a significant effect on attitude toward using (ATU), perceived usefulness (PU) did not. Moreover, perceived ease of use (PEOU) had a significant influence on perceived usefulness (PU), with $p<0.05$. 
Table 6: Hypotheses testing results

\begin{tabular}{|c|l|c|c|c|}
\hline Hypotheses & \multicolumn{1}{|c|}{ Path } & Path coefficient & $t$-value & Results \\
\hline $\mathrm{H}_{1}$ & PU $\longrightarrow$ ATU & 0.67 & 1.10 & Not supported \\
\hline $\mathrm{H}_{2}$ & PEOU $\longrightarrow$ ATU & 0.30 & $3.20^{*}$ & Supported \\
\hline $\mathrm{H}_{3}$ & PEOU $\longrightarrow$ PU & 0.71 & $6.39^{* *}$ & Supported \\
\hline $\mathrm{H}_{4}$ & ATU $\longrightarrow$ BIU & 0.93 & 1.41 & Not supported \\
\hline${ }^{*} p<0.05 ;{ }^{* *} p<0.001$
\end{tabular}

The structural model and hypotheses were tested by examining the path coefficients and their significance. The path coefficients are present in Figure 2. Consistent with our hypotheses, PEOU demonstrated a significant influence on ATU (path $=0.30$ ). Similarly, PEOU demonstrated a significant influence on PU (path $=0.71)$. The link between PU and ATU (path = 0.67) and ATU and BIU (path = 0.93) was non-significant at the 0.5 level of variance. This finding supports current research that demonstrates the strong relationship among PEOU, PU and ATU (Teo, 2009).

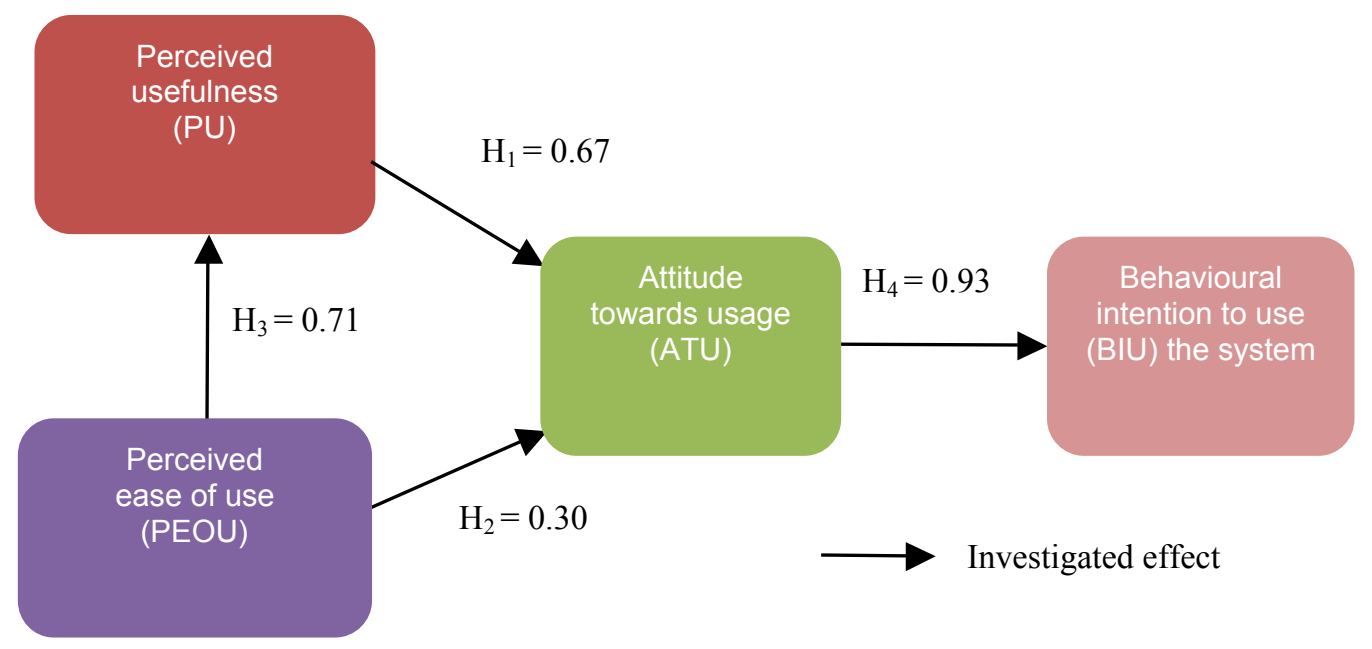

Figure 2: Path coefficient research model results

\section{Limitations and further research}

There are several limitations of the present study that need to be considered. Firstly, the fact that students are individuals, with their own beliefs and values, may have a significant impact on their dispositions. In this study, we relied on self reported measures of the proposed constructs. Since the constructs were composed of individuals' perceptions of personal phenomena, self report methods were necessary. Nonetheless, future work can reduce potential confounds via longitudinal designs, objective procedures and use of behavioural measures. Secondly this study may not fully capture the complexity or periodicity of e-portfolio system usage. Therefore, the results of this study should be viewed as preliminary evidence with respect to examining the relationship of students' intention to use an e-portfolio system. Lastly, future work could be supplemented with other objective measures to avoid response bias and the demand characteristics of the subjects. 
Future research could include studies integrating the technology acceptance model (TAM) and computer self-efficacy (CSE), with a view to examining their combined predictive abilities to explain behavioural intention to use (BIU) among technology users in education. According to Agarwal, Sambamurthy and Stair (2000), the additional construct of computer self-efficacy (CSE) has often been linked with technology acceptance research. Thompson et al. (2006) recommended research to investigate the generalisability of CSE perceptions and to examine its influence in technology acceptance models. Finally, the resultant instrument could be used in future research to test how students value, adopt and accept e-portfolio systems into their learning environment and help extend the TAM at various levels of technology acceptance. The TAM model provided a systemic understanding of students' intentions to use an e-portfolio system; such an understanding can help educators examine their assumptions about students' perceptions concerning the value and acceptance of a new technology.

\section{Discussion and conclusion}

The purpose of this study was to determine if the TAM could legitimately be applied in an e-portfolio paradigm by examining the relationship of students' intention to use an e-portfolio system with selected factors of perceived usefulness (PU), perceived ease of use (PEOU), and attitude towards usage (ATU).

Consistent with prior research (Davis, 1989; Hu et al, 1999), perceived ease of use (PEOU) had a significant effect on attitude towards usage (ATU). An explanation might be that when students perceive the e-portfolio system as one that is easy to use and nearly free of mental effort, they may have a favourable attitude towards the usefulness of the system. These findings support current research which suggests that user's positive feeling towards the ease of use of technology is associated with sustained use of the technology (Yildirim, 2000). The results of the study also showed that perceived ease of use (PEOU) had a significant influence on perceived usefulness (PU). An explanation might be that students are willing to adopt the e-portfolio system, and this may suggest that students tend to focus on the usefulness of the technology itself.

This study did not find a significant relationship between perceived usefulness (PU), attitude towards usage (ATU) and behavioural intention (BIU) to use the e-portfolio system. However, this is consistent with other findings which suggest that the role of ATU in the TAM has been inconclusive. For example, Davis et al. (1989) found that the role of attitude towards usage (ATU) was only modest in predicting technology acceptance and it is possible that users may use a technology even if they do not have a positive attitude towards the technology per se as long as it is perceived to be useful or easy to use. This is supported by Teo and van Schalk (2009) who found that attitude towards computer use did not have a significant influence on intention to use.

This study is a step towards examining students' perceptions of usage of an e-portfolio system that informs their attitude towards usage and their behavioural intention to using the system. E-portfolio systems are a subset of Internet based e-learning technologies, which when utilised, may lack proper evaluation in terms of design, development, assessment and standards. When selecting an e-portfolio system for adoption, it is necessary to identify the features such as the types of artifacts and assessment supported communication and collaboration capabilities, and reflection 
and sharing features that fit the needs of the end users (Swan, 2009). Information systems developers need to take into account the process of development and implementation in terms of increasing the level of acceptance by end users and therefore, predicting various system components, including interfaces, in a way that ensures potential end user satisfaction.

Although emerging educational technology usage in teacher education has increased in recent years, technology acceptance and usage continue to be problematic for educational institutions (Baylor \& Ritchie, 2002; Gong, et al., 2004; Saunders \& Klemming, 2003). Emerging educational technology is often used to provide more flexible approaches to teaching and student' use of emerging educational technology in the classroom is extremely varied. Finally, an understanding of the design of a system can help shift the conventional administrator or faculty mandated design of an e-portfolio system towards a student centered design that more closely resonates with students' perceptions of usage and moreover buy-in and motivation.

\section{Acknowledgments}

The authors would like to acknowledge the valuable contributions of the HKIEd pilot participants, Elson Szeto of the Centre for Learning, Teaching and Technology, Wendy Lam of the English Department, Li Chin Wa of the Department of International Education and Lifelong Learning and Raymond Yuen of the Department of Cultural and Creative Arts.

\section{References}

Abrami, P. C. \& Barret, H. (2005). Directions for research and development on electronic portfolios. Canadian Journal of Learning and Technology, 31(3). http: / / www.cjlt.ca/index.php/cjlt/ article/viewArticle/92/86

Agarwal, R. \& Prasad, J. (1988). A conceptual and operational definition of personal innovativeness in the domain of information technology. Information Systems Research, 9(2), 204-215. http: / / dx.doi.org/10.1287/isre.9.2.204

Agarwal, R. \& Prasad, J. (1997). The role of innovation characteristics and perceived voluntariness in the acceptance of information technologies. Decision Sciences, 28(3), 557-588. http:/ / dx.doi.org/10.1111/j.1540-5915.1997.tb01322.x

Agarwal, R. \& Prasad, J. (1999). Are individual differences germane to the acceptance of new information technologies? Decision Sciences, 30(2), 361-391. http:/ / dx.doi.org/10.1111/j.15405915.1999.tb01614.x

Agarwal, R., Sambamurthy, V. \& Stair, R. (2000). The evolving relationship between general and specific computer self-efficacy: An empirical assessment. Information Systems Research, 11(4), 418-430. http: / / dx.doi.org/10.1111/10.1287/ isre.11.4.418.11876

Ajzen, I. (1991). The theory of planned behavior. Organizational Behavior and Human Decision Processes, 50, 179-211. [verified 13 Jul 2010] http: / / courses.umass.edu/psyc661/pdf/tpb.obhdp.pdf

Ajzen, I. \& Fishbein, M. (1980). Understanding attitudes and predicting social behavior. Englewood Cliffs, NJ: Prentice-Hall.

Ajzen, I. \& Fishbein, M. (2000). Attitudes and the attitude-behavior relation: Reasoned and automatic processes. In W. Stroebe \& M. Hewstone (Eds.), European review of social psychology (pp. 1-33). John Wiley \& Sons. 
Ayala, J. I. (2006). Electronic portfolios for whom? Educause Quarterly, 29(1), 12-13. http: / / www.educause.edu /EDUCAUSE+Quarterly/EDUCAUSEQuarterlyMagazineVolum /ElectronicPortfoliosforWhom/157386

Bagozzi, R. P., Yi, Y. \& Phillips, L. W. (1991). Assessing construct validity in organizational research. Administrative Science Quarterly, 36(3), 421-458. http: / / www.jstor.org/pss / 2393203

Baylor, A. L. \& Ritchie, D. (2002). What factors facilitate teacher skill, teacher morale, and perceived student learning in technology-using classrooms? Computers $\mathcal{E}$ Education, 39(4), 395-414. http: / / dx.doi.org/10.1016/S0360-1315(02)00075-1

Brancheau, J. C. \& Wetherbe, J. C. (1990). The adoption of spreadsheet software: Testing innovation diffusion theory in the context of end-user computing. Information Systems Research, 1(2), 115-143. http:/ / dx.doi.org/10.1287/isre.1.2.115

Chau, J. \& Cheng, G. (2010). Towards understanding the potential of e-portfolios for independent learning: A qualitative study. Australasian Journal of Educational Technology, 26(7), 932-950. http:/ / www.ascilite.org.au/ ajet/ ajet26/ chau.html

Cohen, J. (1977). Statistical power analysis for the behavioral sciences (revised ed.). New York: Academic Press.

Cronbach, L. (1951). Coefficient alpha and the internal consistency of tests. Psychometrika, 297-334.

Cronbach, L. (1970). Essentials of psychological testing (3 ed.). New York: Harper \& Row.

Davis, F. D. (1989). Perceived usefulness, perceived ease of use, and user acceptance of information technology. MIS Quarterly, 13(3), 319-340. http:/ / www.jstor.org/pss / 249008

Davis, F. D. (1993). User acceptance of information technology: System characteristics, user perceptions and behavioral impacts. International Journal of Man-Machine Studies, 38(3), 475487. http:/ / dx.doi.org/10.1006/imms.1993.1022

Davis, F. D., Bagozzi, R. P. \& Warshaw, P. R. (1989). User acceptance of computer technology: A comparison of two theoretical models. Management Science, 35(8), 982-1003. http:/ / www.jstor.org/pss/2632151

Dillon, A. \& Morris, M. (1998). From "can they" to "will they?": Extending usability evaluation to address acceptance. In E. D. Hoadley \& B. Izak (Eds.), Proceedings Association for Information Systems Conference. Baltimore, MD.

Fishbein, M. \& Ajzen, I. (1975). Belief, attitude, intention, and behavior: An introduction to theory and research. Reading, MA: Addison-Wesley.

Gaide, S. (2006). ePortfolio: Supercharge performance-based student assessment. Distance Education Report, 10(2), 14-16.

Gao, Y. (2005). Applying the technology acceptance model (TAM) to educational hypermedia: a field study. Journal of Educational Multimedia and Hypermedia, 14(3), 237-247. http:// www.editlib.org/p/5902

Gefen, D., Straub, D. W. \& Boudreau, M. C. (2000). Structural equation modeling and regression: Guidelines for research practice. Communication of the Association for Information Systems, 4(7), 1-30. [verified 14 Jul 2011] http:/ / www.cis.gsu.edu/ dstraub/Papers/Resume/Gefenetal2000.pdf

Gong, M., Xu, Y. \& Yu, Y. (2004). An enhanced technology acceptance model for Web-based learning. Journal of Information Systems Education, 15(4), 365-373. http: / / www.highbeam.com/ doc/1P3-793505851.html

Hair, J. F., Anderson, R. E., Tatham, R. L. \& Black, W. C. (5th Ed.) (2003). Multivariate data analysis. India: Pearson Education. 
Hu, P. J., Chau, P. Y. K., Sheng, O. R. L. \& Tam, K. Y. (1999). Examining the technology acceptance model using physician acceptance of telemedicine technology. Journal of Management Information Systems, 16(2), 91-112.

Jafari, A. (2002). Conceptualizing intelligent agents for teaching and learning. EDUCAUSE Quarterly, 25(3), 28-34. http:// net.educause.edu/ir/library/pdf/eqm0235.pdf

Jafari, A. (2004). The "sticky" ePortfolio system: Tackling challenges and identifying attributes. EDUCAUSE Review, 39(4), 38-49. http: / / www.educause.edu/EDUCAUSE+Review / EDUCAUSEReviewMagazineVolume39/TheStickyePortfolioSystemTackl/157912

Joyes, G., Gray, L. \& Hartnell-Young, E. (2010). Effective practice with e-portfolios: How can the UK experience inform implementation? Australasian Journal of Educational Technology, 26(1), 15-27. http:/ / www.ascilite.org.au/ajet/ajet26/joyes.html

Kiraz, E. \& Ozdemir, D. (2006). The relationship between educational ideologies and technology acceptance in pre-service teachers. Educational Technology and Society, 9(2), 152-165. http:/ / www.ifets.info/journals/9_2/13.pdf

Kong, S. C., Shroff, R. H. \& Hung, H. K. (2009). A web enabled video system for self reflection by student teachers using a guiding framework. Australasian Journal of Educational Technology, 25(4), 544-588. http:/ / www.ascilite.org.au/ajet/ajet25/ kong.html

Lam, T. C. M. \& Klockars, A. J. (1982). Anchor point effects on the equivalence of questionnaire items. Journal of Educational Measurement, 19, 312-322. http:/ / www.jstor.org/stable/1435004

Lambert, S. \& Corrin, L. (2007). Moving towards a university wide implementation of an ePortfolio tool. Australasian Journal of Educational Technology, 23(1), 1-16. http:/ / www.ascilite.org.au/ajet/ajet23/lambert.html

Liu, S., Liao, H. \& Pratt, J. (2009). Impact of media richness and flow on e-learning technology acceptance. Computers $\mathcal{E}$ Education, 52(3), 599-607. http:/ / dx.doi.org/10.1016/j.compedu.2008.11.002

Ma, Q. \& Liu, L. (2005). The role of Internet self-efficacy in the acceptance of Web-based electronic medical records. Journal of Organizational and End User Computing, 17(1), 38-57. http: / / dx.doi.org/10.4018/joeuc.2005010103

Mathieson, K. (1991). Predicting user intentions: Comparing the technology acceptance model with the theory of planned behavior. Information Systems Research, 2(3), 173-191. http: / / dx.doi.org/10.1287/ isre.2.3.173

McKinnon, K. \& Igonor, A. (2008). Explaining eLearning perceptions using the Technology Acceptance Model and the Theory of Planned Behavior. In C. Bonk et al. (Eds.), Proceedings of World Conference on E-Learning in Corporate, Government, Healthcare, and Higher Education 2008. Chesapeake, VA: AACE. http:/ / www.editlib.org/p/30092

Morris, M. \& Dillon, A. (1997). How user perceptions influence software use. IEEE Software, 14(4), 58-65. http:/ / dx.doi.org/10.1109/52.595956

Nov, O. \& Ye, C. (2008). Users' personality and perceived ease of use of digital libraries: The case for resistance to change. Journal of the American Society for Information Science and Technology, 59(5), 845-851. http: / / dx.doi.org/10.1002/asi.20800

Nunnally, J. (1967). Psychometric theory. New York: McGraw-Hill. 
Orland-Barak, L. (2005). Portfolios as evidence of reflective practice: What remains 'untold'. Educational Research, 47(1), 25-44. http:/ / dx.doi.org/10.1080/0013188042000337541

Park, N. (2009). User acceptance of e-learning in higher education: An application of Technology Acceptance Model. Paper presented at the Annual meeting of the International Communication Association, New York.

Pearlson, K. E., \& Saunders, C. S. (2006). Managing \& using information systems: A strategic approach. John Wiley \& Sons.

Pelliccione, L. \& Raison, G. (2009). Promoting the scholarship of teaching through reflective eportfolios in teacher education. Journal of Education for Teaching, 35(3), 271-281. http: / / dx.doi.org/10.1080/02607470903092813

Saunders, G. \& Klemming, F. (2003). Integrating technology into a traditional learning environment. Active Learning in Higher Education, 4(1), 74-86. http: / / dx.doi.org/10.1177/1469787403004001006

Sugar, W., Crawley, F. \& Fine, B. (2004). Examining teachers' decisions to adopt new technology. Educational Technology and Society, 7(4), 201-213. http:/ / www.ifets.info/journals/7_4/19.pdf

Swan, G. (2009). Examining barriers in faculty adoption of an e-portfolio system. Australasian Journal of Educational Technology, 25(5), 627-644. http: / / www.ascilite.org.au/ajet/ajet25/swan.html

Taylor, S. \& Todd, P. (1995). Assessing IT usage: The role of prior experience. MIS Quarterly, 19(4), 561-570. http:/ / www.misq.org/cat-articles / assessing-it-usage-the-role-of-priorexperience.html

Teo, T. (2009). Modelling technology acceptance in education: A study of pre-service teachers. Computers \& Education, 52(2), 302-312. http:/ / dx.doi.org/10.1016/j.compedu.2008.08.006

Teo, T. \& van Schalk, P. (2009). Understanding technology acceptance in pre-service teachers: A structural-equation modeling approach. The Asia-Pacific Education Researcher, 18(1), 47-66. http: / / ejournals.ph/index.php?journal=TAPER\&page=article\&op=view\&path\%5B $\% 5 \mathrm{D}=1029$

Thompson, R., Compeau, D. \& Higgins, C. (2006). Intentions to use information technologies: An integrative model. Journal of Organizational and End User Computing, 18(3), 25-43. http: / / dx.doi.org/10.4018/joeuc.2006070102

Venkatesh, V., Morris, M. G., Davis, F. D. \& Davis, G. B. (2003). User acceptance of information technology: Toward a unified view. MIS Quarterly, 27(3), 425-478. http://www.jstor.org/pss/30036540

Yi, M. \& Hwang, Y. (2003). Predicting the use of web-based information systems: Self-efficacy, enjoyment, learning goal orientation, and the technology acceptance model. International Journal of Human-Computer Studies, 59, 431-449. http:/ / dx.doi.org/10.1016/S10715819(03)00114-9

Yildirim, S. (2000). Effects of an educational computing course on preservice and inservice teachers: A discussion and analysis of attitudes and use. Journal of Research on Computing in Education, 32(4), 479-495.

Zhang, S. X., Olfman, L. \& Reetham, P. (2007). Designing eportfolio 2.0: Integrating and coordinating web 2.0 services with eportfolio systems for enhancing users' learning. Journal of Information Systems Education, 18(2), 203-214. http: / / jise.org/Issues / 18/V18N2P203-Abs.pdf 


\section{Appendix: E-portfolio usage survey}

\begin{tabular}{|c|c|c|c|}
\hline \multirow{2}{*}{\multicolumn{4}{|c|}{\begin{tabular}{|l|} 
Survey variables and codes \\
SECTION I
\end{tabular}}} \\
\hline & & & \\
\hline \multirow{4}{*}{1} & \multirow{4}{*}{$\begin{array}{l}\text { Have you used or created an e-Portfolio before taking } \\
\text { this class? }\end{array}$} & Value & Code \\
\hline & & \begin{tabular}{|l|l} 
Never \\
Once
\end{tabular} & $\frac{1}{2}$ \\
\hline & & Two to three times & 3 \\
\hline & & More than three times & 4 \\
\hline \multirow[t]{9}{*}{2} & \multirow{9}{*}{$\begin{array}{l}\text { During this course, how often have you reviewed, } \\
\text { interacted with, or added to the course e-Portfolio? }\end{array}$} & Not at all & 1 \\
\hline & & About once each month & 2 \\
\hline & & A few times a month & 3 \\
\hline & & About once each week & 4 \\
\hline & & A few times a week & 5 \\
\hline & & Five to six times a week & 6 \\
\hline & & About once a day & 7 \\
\hline & & Several times a day & 8 \\
\hline & & Other & 9 \\
\hline \multirow[t]{3}{*}{3} & \multirow{3}{*}{ What is your self-assessment about using e-Portfolio? } & Low experience & 1 \\
\hline & & Moderate experience & 2 \\
\hline & & High experience & 3 \\
\hline \multirow[t]{3}{*}{4} & \multirow{3}{*}{$\begin{array}{l}\text { After working with the e-Portfolio in this class, how } \\
\text { experienced would you judge yourself to be? }\end{array}$} & Low-level experience & 1 \\
\hline & & Moderately experienced & 2 \\
\hline & & Highly experienced & 3 \\
\hline \multirow[t]{3}{*}{5} & \multirow{3}{*}{$\begin{array}{l}\text { With regard to technology in general, how would you } \\
\text { describe yourself? }\end{array}$} & Novice User & 1 \\
\hline & & Intermediate User & 2 \\
\hline & & Advanced User & \\
\hline \multirow[t]{2}{*}{6} & \multirow[t]{2}{*}{ Gender } & Female & 1 \\
\hline & & Male & 2 \\
\hline \multirow[t]{4}{*}{7} & \multirow[t]{4}{*}{ Your year in school } & 1 & 1 \\
\hline & & 2 & 2 \\
\hline & & 3 & \\
\hline & & 4 & \\
\hline \multicolumn{4}{|c|}{ SECTION II } \\
\hline \multirow[t]{7}{*}{8} & \multirow{7}{*}{$\begin{array}{l}\text { I have a generally favorable attitude toward using the } \\
\text { e-Portfolio System. }\end{array}$} & Strongly Agree & 7 \\
\hline & & Moderately Agree & 6 \\
\hline & & Slightly Agree & 5 \\
\hline & & Neutral & 4 \\
\hline & & Slightly Disagree & 3 \\
\hline & & Moderately Disagree & 2 \\
\hline & & Strongly Disagree & 1 \\
\hline \multirow[t]{7}{*}{9} & \multirow{7}{*}{$\begin{array}{l}\text { Using the e-Portfolio enhanced my effectiveness in } \\
\text { learning. }\end{array}$} & Strongly Agree & 7 \\
\hline & & Moderately Agree & 6 \\
\hline & & Slightly Agree & 5 \\
\hline & & Neutral & 4 \\
\hline & & Slightly Disagree & 3 \\
\hline & & Moderately Disagree & 2 \\
\hline & & Strongly Disagree & 1 \\
\hline \multirow[t]{7}{*}{10} & I intend to use the e-Portfolio during the semester. & Strongly Agree & 7 \\
\hline & & Moderately Agree & 6 \\
\hline & & Slightly Agree & 5 \\
\hline & & Neutral & 4 \\
\hline & & Slightly Disagree & 3 \\
\hline & & Moderately Disagree & 2 \\
\hline & & Strongly Disagree & 1 \\
\hline
\end{tabular}




\begin{tabular}{|c|c|c|c|}
\hline \multirow[t]{7}{*}{11} & \multirow{7}{*}{$\begin{array}{l}\text { I intend to use the e-Portfolio frequently for my } \\
\text { coursework. }\end{array}$} & Strongly Agree & 7 \\
\hline & & Moderately Agree & 6 \\
\hline & & Slightly Agree & 5 \\
\hline & & Neutral & 4 \\
\hline & & Slightly Disagree & 3 \\
\hline & & Moderately Disagree & 2 \\
\hline & & Strongly Disagree & 1 \\
\hline \multirow[t]{7}{*}{12} & \multirow{7}{*}{$\begin{array}{l}\text { Overall, I found the e-Portfolio interface on Blackboard } \\
\text { easy to use. }\end{array}$} & Strongly Agree & 7 \\
\hline & & Moderately Agree & 6 \\
\hline & & Slightly Agree & 5 \\
\hline & & Neutral & 4 \\
\hline & & Slightly Disagree & 3 \\
\hline & & Moderately Disagree & 2 \\
\hline & & Strongly Disagree & 1 \\
\hline \multirow[t]{7}{*}{13} & \multirow{7}{*}{$\begin{array}{l}\text { I believe it is a good idea to use the e-Portfolio System } \\
\text { for my coursework. }\end{array}$} & Strongly Agree & 7 \\
\hline & & Moderately Agree & 6 \\
\hline & & Slightly Agree & 5 \\
\hline & & Neutral & 4 \\
\hline & & Slightly Disagree & 3 \\
\hline & & Moderately Disagree & 2 \\
\hline & & Strongly Disagree & 1 \\
\hline \multirow[t]{7}{*}{14} & \multirow{7}{*}{$\begin{array}{l}\text { Using the e-Portfolio improved my course } \\
\text { performance. }\end{array}$} & Strongly Agree & 7 \\
\hline & & Moderately Agree & 6 \\
\hline & & Slightly Agree & 5 \\
\hline & & Neutral & 4 \\
\hline & & Slightly Disagree & 3 \\
\hline & & Moderately Disagree & 2 \\
\hline & & Strongly Disagree & 1 \\
\hline \multirow[t]{7}{*}{15} & \multirow[t]{7}{*}{ I intend to use the e-Portfolio as often as possible. } & Strongly Agree & 7 \\
\hline & & Moderately Agree & 6 \\
\hline & & Slightly Agree & 5 \\
\hline & & Neutral & 4 \\
\hline & & Slightly Disagree & 3 \\
\hline & & Moderately Disagree & 2 \\
\hline & & Strongly Disagree & 1 \\
\hline \multirow[t]{7}{*}{16} & \multirow{7}{*}{$\begin{array}{l}\text { Learning to use the e-Portfolio interface on Blackboard } \\
\text { was easy for me. }\end{array}$} & Strongly Agree & 7 \\
\hline & & Moderately Agree & 6 \\
\hline & & Slightly Agree & 5 \\
\hline & & Neutral & 4 \\
\hline & & Slightly Disagree & 3 \\
\hline & & Moderately Disagree & 2 \\
\hline & & Strongly Disagree & 1 \\
\hline \multirow[t]{7}{*}{17} & \multirow[t]{7}{*}{ I like the idea of using the e-Portfolio System. } & Strongly Agree & 7 \\
\hline & & Moderately Agree & 6 \\
\hline & & Slightly Agree & 5 \\
\hline & & Neutral & 4 \\
\hline & & Slightly Disagree & 3 \\
\hline & & Moderately Disagree & 2 \\
\hline & & Strongly Disagree & 1 \\
\hline \multirow[t]{7}{*}{18} & \multirow{7}{*}{$\begin{array}{l}\text { Using the e-Portfolio increased my productivity in my } \\
\text { coursework. }\end{array}$} & Strongly Agree & 7 \\
\hline & & Moderately Agree & 6 \\
\hline & & Slightly Agree & 5 \\
\hline & & Neutral & 4 \\
\hline & & Slightly Disagree & 3 \\
\hline & & Moderately Disagree & 2 \\
\hline & & Strongly Disagree & 1 \\
\hline
\end{tabular}




\begin{tabular}{|c|c|c|c|}
\hline \multirow[t]{7}{*}{19} & \multirow{7}{*}{$\begin{array}{l}\text { My interaction with the e-Portfolio interface on } \\
\text { Blackboard was clear and understandable. }\end{array}$} & Strongly Agree & 7 \\
\hline & & Moderately Agree & 6 \\
\hline & & Slightly Agree & 5 \\
\hline & & Neutral & 4 \\
\hline & & Slightly Disagree & 3 \\
\hline & & Moderately Disagree & 2 \\
\hline & & Strongly Disagree & 1 \\
\hline \multirow[t]{7}{*}{20} & \multirow{7}{*}{$\begin{array}{l}\text { Using the e-Portfolio enabled me to accomplish tasks } \\
\text { more quickly. }\end{array}$} & Strongly Agree & 7 \\
\hline & & Moderately Agree & 6 \\
\hline & & Slightly Agree & 5 \\
\hline & & Neutral & 4 \\
\hline & & Slightly Disagree & 3 \\
\hline & & Moderately Disagree & 2 \\
\hline & & Strongly Disagree & 1 \\
\hline \multirow[t]{7}{*}{21} & \multirow{7}{*}{$\begin{array}{l}\text { It was easy for me to become skillful at using the e- } \\
\text { Portfolio interface on Blackboard. }\end{array}$} & Strongly Agree & 7 \\
\hline & & Moderately Agree & 6 \\
\hline & & Slightly Agree & 5 \\
\hline & & Neutral & 4 \\
\hline & & Slightly Disagree & 3 \\
\hline & & Moderately Disagree & 2 \\
\hline & & Strongly Disagree & 1 \\
\hline \multirow[t]{7}{*}{22} & \multirow{7}{*}{$\begin{array}{l}\text { Using the e-Portfolio System provided me with a lot of } \\
\text { enjoyment. }\end{array}$} & Strongly Agree & 7 \\
\hline & & Moderately Agree & 6 \\
\hline & & Slightly Agree & 5 \\
\hline & & Neutral & 4 \\
\hline & & Slightly Disagree & 3 \\
\hline & & Moderately Disagree & 2 \\
\hline & & Strongly Disagree & 1 \\
\hline \multirow[t]{7}{*}{23} & \multirow[t]{7}{*}{ I plan to use the e-Portfolio in the future. } & Strongly Agree & 7 \\
\hline & & Moderately Agree & 6 \\
\hline & & Slightly Agree & 5 \\
\hline & & Neutral & 4 \\
\hline & & Slightly Disagree & 3 \\
\hline & & Moderately Disagree & 2 \\
\hline & & Strongly Disagree & 1 \\
\hline \multirow[t]{7}{*}{24} & \multirow{7}{*}{$\begin{array}{l}\text { I expect my use of the e-Portfolio to continue in the } \\
\text { future. }\end{array}$} & Strongly Agree & 7 \\
\hline & & Moderately Agree & 6 \\
\hline & & Slightly Agree & 5 \\
\hline & & Neutral & 4 \\
\hline & & Slightly Disagree & 3 \\
\hline & & Moderately Disagree & 2 \\
\hline & & Strongly Disagree & 1 \\
\hline \multirow[t]{7}{*}{25} & \multirow[t]{7}{*}{ I found using the e-Portfolio useful. } & Strongly Agree & 7 \\
\hline & & Moderately Agree & 6 \\
\hline & & Slightly Agree & 5 \\
\hline & & Neutral & 4 \\
\hline & & Slightly Disagree & 3 \\
\hline & & Moderately Disagree & 2 \\
\hline & & Strongly Disagree & 1 \\
\hline \multirow[t]{7}{*}{26} & \multirow[t]{7}{*}{ Overall, I enjoyed using the e-Portfolio System. } & Strongly Agree & 7 \\
\hline & & Moderately Agree & 6 \\
\hline & & Slightly Agree & 5 \\
\hline & & Neutral & 4 \\
\hline & & Slightly Disagree & 3 \\
\hline & & Moderately Disagree & 2 \\
\hline & & Strongly Disagree & 1 \\
\hline
\end{tabular}




\begin{tabular}{|l|l|l|c|}
\hline 27 & $\begin{array}{l}\text { I found the e-Portfolio interface on Blackboard to be } \\
\text { flexible to interact with. }\end{array}$ & Strongly Agree & 7 \\
\cline { 3 - 4 } & Moderately Agree & 6 \\
\cline { 3 - 4 } & Slightly Agree & 5 \\
\cline { 3 - 3 } & Neutral & 4 \\
\cline { 3 - 4 } & Slightly Disagree & 3 \\
\cline { 3 - 4 } & Moderately Disagree & 2 \\
\cline { 3 - 4 } & Strongly Disagree & 1 \\
\hline
\end{tabular}

Authors: Dr Ronnie H. Shroff (corresponding author)

Assistant Professor, Centre for Learning, Teaching and Technology (LTTC)

The Hong Kong Institute of Education

B4-P-02G1, 10 Lo Ping Road, Tai Po, New Territories, Hong Kong

Email: rshroff@ied.edu.hk

Dr Christopher C. Deneen

Research Assistant Professor, Division of English Language Education

Faculty of Education, The University of Hong Kong

(formerly Assistant Professor, Centre for Learning, Teaching and Technology

The Hong Kong Institute of Education. Email: deneen@ied.edu.hk)

Dr Eugenia M. W. Ng

Associate Professor, Department of Mathematics and Information Technology

The Hong Kong Institute of Education

D4-1/F-06, 10 Lo Ping Road, Tai Po, New Territories, Hong Kong

Email: eugenia@ied.edu.hk

Please cite as: Shroff, R. H., Deneen, C. D. \& Ng, E. M. W. (2011). Analysis of the technology acceptance model in examining students' behavioural intention to use an e-portfolio system. Australasian Journal of Educational Technology, 27(4), 600-618.

http: / / www.ascilite.org.au / ajet/ajet27/ shroff.html 